1988

\title{
Social Control: Analytical Tool or Analytical Quagmire?
}

Shelley A. M. Gavigan

Osgoode Hall Law School of York University, sgavigan@osgoode.yorku.ca

Dorothy E. Chunn

Source Publication:

Contemporary Crises. Volume 12 (1988), p. 107-124.

Follow this and additional works at: https://digitalcommons.osgoode.yorku.ca/scholarly_works

Part of the Law and Gender Commons, and the Law and Philosophy Commons

(c) (1) $(9)$

This work is licensed under a Creative Commons Attribution-Noncommercial-No Derivative Works 4.0 License.

\section{Recommended Citation}

Gavigan, Shelley A. M., and Dorothy E. Chunn. "Social Control: Analytical Tool or Analytical Quagmire?." Contemporary Crises 12 (1988): 107-124.

This Article is brought to you for free and open access by the Faculty Scholarship at Osgoode Digital Commons. It has been accepted for inclusion in Articles \& Book Chapters by an authorized administrator of Osgoode Digital Commons. 


\section{Social control: analytical tool or analytical quagmire?*}

\section{DOROTHY E. CHUNN ${ }^{1} \&$ SHELLEY A.M. GAVIGAN ${ }^{2}$}

${ }^{1}$ School of Criminology, Simon Fraser University, Burnaby, British Columbia, Canada; ${ }^{2}$ Osgoode Hall Law School, York University, North York, Ontario, Canada

I find Social Control a key that unlocks many doors.

$$
\text { E. A. Ross }
$$

The term 'social control' has lately become something of a Mickey Mouse concept.

\section{S. Cohen}

There is probably no concept which is used more widely and with less precision than that of 'social control' ${ }^{1}$ Given the lack of agreement about what 'social control' is, researchers usually employ the term in one of two ways. Either they assume that its meaning is obvious and requires no clarification; or, they begin with a perfunctory acknowledgment of the definitional problems associated with the concept and proceed to use it anyway. The eclecticism of the latter approach has stimulated attempts over the years to produce a universally applicable definition of 'social control' that could be employed both system- atically and scientifically in research (Clark and Gibbs 1965, Gibbs 1977, Janowitz 1978, Mayer 1983). While these efforts are commendable and may ultimately prove fruitful, the ongoing elusiveness of such a formulation has led us in a different direction. We have concluded that the concept of 'social control' incorporates ambiguities which severely undermine its effectiveness as an analytical tool. The argument is developed in two stages: first, by tracing the historical evolution of the concept to illustrate the problematic nature of a 'social control' model; and second, by demonstrating, through an assessment of

\footnotetext{
* Paper presented at the Annual Meeting of the Canadian Association of Sociology and Anthro- pology, 4-7 June 1986, Winnipeg, Manitoba. Equal authorship.
} 
the 'women, law and social control' literature, its inadequacy as an analyt- ical construct. $^{2}$

\section{'Social control' and American sociology; one model fits all}

To understand the limitations of the concept of 'social control' requires a brief discussion of its historical origins and subsequent elaboration. Janowitz (1975: 82, see also 1976; 1978) points out that the term was first used by the classical nineteenth-century European theorists to draw a link between sociology and social philosophy. However, there seems to be express agreement that the selfconscious formulation of 'social control' as an analytical concept and its utilization in sociological research were the accomplishments of American academics (Schwendinger and Schwendinger 1974: 198-221, Janowitz 1975: 87, 1978: 33, Brown 1978: n.1., Hunt 1978: 19-20, Gibbons 1979, Adlam and Rose 1981, Cohen and Scull 1983: 5-7). Since the 1890s, American sociologists have formulated two definitions of 'social control' which, although seemingly contradictory, share a common focus; namely, the question of how social order is maintained in pluralist democracies, specifically the United States. One definition is premised on the assumption that societal integration is achieved through the operation of numerous non-coercive social control pro- cesses; the other on the belief that coercive state control mechanisms, partic- ularly law, play the most crucial role in reproducing the status quo (Janowitz 1975, 1978; Rothman 1981; Cohen 1985).

Both versions of 'social control' have been products of the functionalist and interactionist strands within American sociology. What might be called the 
benign formulation originated in the work of E.A. Ross during his tenure at Stanford University (Ross 1969: xv; see also Geis 1964, Schwendinger and Schwendinger 1974); wound its way via the pages of the American Journal of Sociology into the writings of various Chicago School members (Cooley 1966, Park andBurgess 1969: c.1, c.12); and from there into the thought and publications of Talcott Parsons (1951). The basic concern of all these men was to explain how 'fundamental harmony' and 'cooperation' were being achieved in America without frequent recourse to or reliance on 'coercion or external discipline' (Rothman 1981: 11). What they concluded was that informal, noninstitutionalized mechanisms of social control, 'located in primary social activities', were the key to the maintenance of social order (Hunt 1978: 147). Thus, social control was viewed primarily 'in terms of the socialisation process operating through the internalization of values' ( $i b i d$ ). It is this conception of 'social control' which has surfaced in the work of some contemporary control theorists (Reckless 1961, Hirschi 1969, Downes and Rock 1982, c.9). ${ }^{3}$

The conception of social control as organized repression emerged in the 1960s and 1970s and owed an intellectual debt to the observations of Tannenbaum (1938) and Lemert $(1951,1967)$ about the deleterious effects of official stigmatization. The idea that the social control exercised by state agents produced and reinforced deviance was extensively elaborated and refined by the neo-Chicagoan labelling theorists of the 1960s and 1970s. During the same period, radical deviancy theorists (Quinney 1974, Spitzer 1975, Chambliss 1976, Platt 1977) developed macro analyses of the functions served by the essentially undemocratic and coercive character of the institutions used by 'top dogs' or ruling classes to impose their will on the exploited underclasses in American 
society (Rothman 1981, Cohen 1985). Premised onnotions of coercion and cooptation, the 'new' version of 'social control' constituted an apparently severe critique of the existing capitalist social order in the United States. The concept of 'social control' as 'doing good' had become the concept of 'social control' as 'doing bad'.

It is important to emphasize how tremendously influential the concept of social control hasbeen amongAnglo-American sociologists of deviance throughout the twentieth century. Researchers applied the concept in one sphere after another until it was eventually 'taken for granted' that weak or strong, informal or formal controls were 'manifest in every single phase of social life' (Schwendinger and Schwendinger 1974: 203; see also Janowitz 1975, 1978: 39-44). Moreover, both the benign and coercive definitions of social control have been widely adopted by academics in other disciplines such as law (Pound 1930, 1942) and history (Stedman Jones 1977, Pisciotta 1981, Mayer 1983). Thus, to a great extent, the discourse of North American sociology and that of related disciplines in the twentieth century has been, and is, the discourse of social control. Functionalists and interactionists, marxists and non-marxists all employ the concept, many uncritically, assuming that its meaning is one of the two previously outlined.

But, from the late 1970 s, the recognition has spread that 'social control' is an extremely problematic term. Brown (1978: 126; see also Hay 1978: 107) describes it as 'an ambiguous concept' which is difficult to use in research because definitions vary and the range of phenomena to which 'social control' is applied varies as well. However, despite these acknowledgments, many academics argue that it would be exceedingly difficult to coin a superior concept 'to describe the processes by which society is preserved from disruption'; they express optimism that the problems associated with the term 'social 
control' can be eliminated through 'clear definition and consistent use of the concept' (Hay 1978: 108; see also Janowitz 1978, Mayer 1983). Indeed, a number of sociologists are presently engaged in attempts to formulate system- atic theories of social control (Davis 1980, Anderson and Davis 1983, Melossi 1985).

However, the hegemony of the concept is not absolute. On the contrary, some trenchant criticisms of the term have appeared in recent years (Muraskin 1976, Schwendinger and Schwendinger 1974, Stedman Jones 1977, Hall et al. 1978, Corrigan and Sayer 1981, Hall and Scraton 1981, Rothman 1981). De- spite the faith of its adherents, therefore, critics have maintained that the concept of 'social control' suffers from some very serious flaws which stunt its efficacy as an analytical tool, and provide good reason for its abandonment by critical academics.On the one hand, they argue that, as an American'invention' and export, the term is characterized by a certain ethnocentricity and is thus unavoidably encumbered with the ideological baggage ofliberalism. On the other, they point to the fact that, whether we are speaking about the benign or coercive formulation of 'social control', researchers use the concept as if it is a universally applicable one.

What this means, then, is that a 'social control' model is essentially ahistor ical and determinist. These criticisms are elaborated by Hall et al. (1978: 195) in a short, but damning, comment which indicts what they call the contemporary 'control-culture' approach for its lack of focus on historically-specific types of state or political regime. Thus, the 'social control' model fails to distinguish not only between different kinds of social formations but also between social formations of the same general type (for example, market societies). Rather, it suggests either the natural evolution of informal/formal social controls or the arbitrary imposition of controls by state agents and agencies. Moreover, although inextricably tied to the liberal democratic, capitalist social formations of the twentieth century, the 
concept of social control as employed by researchers frequently becomes a determinist one because it is devoid of any theorization of the state. The latter, then, remains an undifferentiated entity in both the benign and coercive formulations of 'social control'. In the former, it either assumes the role of neutral arbiter or acts as an advocate of the 'best interests' of citizens (Ross 1969). In the latter, it is reified as an omnipotent, essentially malevolent Leviathan (Matza 1969). These monolithic formulations leave little room for resistance or self-determi- nation collective or individual on the part of those who are controlled.

We agree with the critics about the ahistorical, determinist character of the 'social control' model. Indeed, when placed in context, both the benign and coercive definitions of social control are clearly linked to specific configurations of social conditions that promoted their ascendancy at particular points in time. Thus, Ross's concept of social control was the result of his attempts to confront and explain the extensive social change that was sweeping the United States and other Western market societies in the late nineteenth century. A coalescence of political, economic and demographic lines of development namely, urbanization, industrialization and universal suffrage during the period from the 1880 s to the 1930s created the foundations of the welfare state (Garland 1981, 1985, Hall 1984). In America, the upheaval wrought by these changes was exacerbated by the influx of numerous ethnic, religious and national groups from Europe as well as massive internal migration from farms to cities.

While Durkheim was describing the movement from mechanical to organic solidarity, then, Ross (1969) was simultaneouslydiscussing the shift from natural, undifferentiated societies to composite or differentiated ones. This evolutionaryprocess, heargued, was characterizedby theemergenceof private property and free enterprise; the growth of impersonal and transient urban 
relationships; and a high degree of occupational mobility, deterioration of marriage, kinship and religious traditions and technological change (Ross 1969; see also Schwendinger and Schwendinger 1974: 204-211). 'Social con- trol' emerged as the pivotal concept in a reformulation of liberalism which accompanied the ideological shift from an emphasis on individualism and the minimal state characteristic of the classical laissez-faire state to a focus on individualization and the interventionist state characteristic of the social welfare state (Garland 1985). Ross perceived the United States in ideal-type terms as a 'classless' or 'democractic' form of society where 'social control' would ultimately replace class conflict and class control (Ross 1969: 376-395).

As a quintessential Progressive, Ross did not believe that capitalism and social classes could or should be eliminated but he was convinced that the rough edges could be smoothed off and disruptive conflicts between individuals and groups eliminated. In addition to the state functioning as the in- stitutional arena for conflict resolution, Ross also envisaged other kinds of relationships which would prevent selfish interest groups from dominating differentiated societies (ibid). Thus, although capitalists were strong, counter- vailing forces of 'public opinion', tradition and enlightened politicians(for example, Theodore Roosevelt) would maintain a balance. Ross and his 'progressive' successors, then, formulated a concept of 'social control' premised on assumptions about harmony, cooperation and progress. As the benign concept of 'social control' worked its way into the work of the pre-WWII functionalists and from there into modern American sociological thought (Hunt 1978: 19), it increasingly came to mean the 'scientific management' of people by technocrats and experts. Confident of their ability to 'do good', psychologists, social workers and other professionals provided assistance in the mobilization of various resources for the production of conformity. 
However, the coercive version of 'social control', which made its debut in the 1960s and was refined during the 1970s, strongly challenged the conventional assumption that informal social controls were the fundamental basis, or essence of social order. Like its benign counterpart, the repressive model of 'social control' emerged within the context of particular historical conditions. Some contemporary analysts (Scull 1977, Cohen 1985) argue that another fundamental restructuring of Western market societies is in progress. While this has not yet been demonstrated unequivocally, it can definitely be established that a widespread perception of 'crisis' -fiscal, political, legal -in liberal democracies formed the backdrop for the reconceptualization of 'social control' (Unger 1976, Scull 1977, Hall et al. 1978,Janowitz 1978). Indeed, radical criminologists, sociologists and historians not only brought 'control', in the sense of repressive state control, to centre stage but also called for forms of political practice linked to such a conception (Garland and Young 1983: 6).

Unfortunately, the radical promise of these 'social control' theorists has not been realized. Their critique remains underdeveloped; in radical analyses, 'control' remains a 'vague force' and revolutionary politics have been confined almost exclusively 'to the written page or conducted in abstract' (ibid). In some ways, then, the coercive formulation of 'social control' does not represent an advance over the traditional theorizing about it. As Garland has suggested in another context, 'A philosophical inversion is not in itself a theoretical ad- vance' (1983: 50). Thus, the presumed critical function of the coercive model of 'social control' can be seriously questioned.

At the same time, although no 'systematic accounts' of 'control' have been produced, radical theorists tend to assume that any 'control' is in and of itself bad or 
unjust. Such an assumption has led to what Adlam and Rose (1981) call the 'tedious repetition' of 'unmaskings' of the social control functions of psychiatry, medicine, social policy and the welfare state, as well as the criminal law. This denunciation of the state and all its works is not radical, however, because everything and therefore nothing can count as an instance of repressive social control (ibid). The controlled, then, are passive robots at the mercy of a carceral apparatus which expands almost daily. But to what extent do people voluntarily participate in their own subjugation? To what degree do they receive genuine assistance from the people who presumably control them? To what extent do individuals and groups resist efforts to repress them? These are questions which we believe cannot be addressed within the con- straints of a 'social control' model.

\section{Law as social control: obvious or obfuscation?}

The limitations of the 'social control' model become more apparent when the implications of its coupling with law are examined. Yet, despite (or perhaps because of) the frequent use in the literature of the law and social control couplet, which is enjoying a certain renaissancein both criminology and sociology of law, in literature of both critical (see, e.g., Greenaway and Brickey 1978, Hamner 1981, Scull and Cohen 1983, Ratner and McMullen 1985, Snider 1985, Boyd 1986) and non-critical literature alike (see, e.g., Black 1978, Hagan et al. 1979, Yago 1981, Gibbs 1982), what is curious is the absence of any serious interrogation of this pairing. It seems that the social reality of law, its raison d'etre, is pure, simple and obvious: it is an instrument of (social) control. And yet, its appeal is precisely the trap: because of its 'somewhat self-evident character there 
has been insufficient attention to the implications that flow from the "law as social control" perspective' (Hunt 1978: 146).

In the non-critical socio-legal literature, resort to the formal social control of law is said to be had when informal methods of control are no longer available or capable of producing acquiescence. The formal shores up or enforces the values of the informal. The baldest (if admittedly least critical) restatement of law as social control is found in the work of Donald Black (1976; 1978). Social control is the 'normative aspect of social life ... which defines and responds to deviant behaviour' (1978: 105); Black defines (rather than locates) law as 'governmental social control' (1978: 2). He eschews a jurisprudential approach to the sociology of law: law is simply 'behaviour', a quantifiable, measurable variable:

The quantity of law varies in time and space. It varies across centuries, decades and years, months and days, even the hours of the day. It varies across societies, regions, communities, neighborhoods, families, and rela- tionships of every kind. Itvaries across the world and its history, the settings of a society or community, the cases in a court, the daily round of a policeman(1978: 3-4).

Black's conception of law as social control is not particularly innovative and can be characterized as an updated restatement of Durkheim (Menzies 1983); however, it is important because of its influence in sociology of law and in criminology. But beyond that, Black's work both exemplifies and illustrates the weakness of the perspective: law is exclusively bound up with the notion of sanctioning 'deviant behaviour' and it explicitly denies the importance of historical specificity. In his sociology of law, the formal social control of law is a natural and inevitable 
consequence of social life:

The constraint of society over its members is thus the constraint that flows naturally from the primary constituents of social life itself. The constraint that is exercised through the informal mechanisms of social control is seen as being essentially a process of self-regulation endemic in the postulation of social life itself . Now, if law is regarded as one of the forms of social control there is implied a view that they form a continuum ranged along a scale from informal means to the more institutionalised forms of which law is regarded as the most specialised form (Hunt 1976: 27-28).

This notion of a continuum between informal and formal is not confined to the noncritical literature in the sociology of law. Indeed, the radical social control literature evinces the same commitment, although the formal enforcement of informal relations is given a coercive edge. However, within this literature, even the apparent retreat from formality is seen to be a trick, or as Maureen Cain has observed, 'a disguised form of state expansion' (1985: 339).

The commitment of radical social theorists to a conception of social control is puzzling. As we have argued above, one is bound to ask what is social about the control of law and how are we to identify its manifestations? Is all law committed to social control? What is the role of the state? Of ideology? Admittedly these are questions not even posed by the mainstream writers. However, if the answers to these questions seem obvious to some, it is, we would argue, because critical scholars have not been inclined to seriously interrogate the social reality of law in different historical contexts, but rather have been 
content to apply a priori theories to the place of law.

Despite its powerful challenge to the hegemony of jurisprudence in the sociology of law (see Hunt 1976, 1978), one must query the analytical utility of conceptualizing law as simply a form of 'social control', with or without a coercive edge. How, if at all, can it facilitate our understanding of resistance, struggle and social change? Can it help us understand the nature and significancein shifts in both the position and the role, as well as the content, of law in different historical contexts (see Hall et al. 1978, Hall 1980, Smart 1984)? As Gareth Stedman Jones has argued:

There is no political or ideological institution which could not in some way be interpreted as an agency of social control. There is no indication in the phrase of who the agents or instigators of social control may be: no in- dication of any common mechanism whereby social control is enforced: no constant criterion whereby we may judge whether social control has broken down ... (1977: 164).

In its narrow emphasis on the sanctioning of deviance by the imposition of controls, the possibility of understanding whole social formations and whole legal systems the totality rather than a segment is neglected (Sugarman 1983: 214). This then highlights yet another problematic aspect of the 'law as social control' perspective: the focus is invariably upon criminal law, penal law, and forms of administrative law such as welfare and mental health law, and the emphasis is upon the manipulative, 'containing' aspects of that law. Just as Hunt (1982) has criticized the coercion-consent dichotomy within sociology of law, so too it is clear that within both the 'benign' and 'critical' social control perspectives the dichotomy is reinforced with different emphasis: the law either controls or coerces - 
the result is the same: the targeting of a problem population for control.

As we have suggested above, the concept has been employed in radical critiques of law to attempt to expose and demystify liberal and legislative reforms and policies (of which there are fewer and fewer in the current context). As a result, the work of critical 'social control' theorists must be located at the 'instrumentalist' level of marxist theorizing on law (see Hunt 1981a), adopting (albeitly implicitly) a rejection of law as a (useful) site of struggle, coupled with a desire to unmask the dark side of the legal reform.

Hunt himself does not address the 'critical' social control literature; however, we would argue that it finds its place in his conceptualization of 'instrumentalist' theorizing on law. This is important, because although Hunt cogently argues that within the 'law as social control' perspective there is a tendency to neglect the coercive character of law (1976: 28, 1978: 147, 1981a: 96), it is clear that within the radical/critical social control literature there is identifieda thinly masked coercive edge to the thrust of 'legal control'.

\section{Formal and informal control}

Within the 'law as social control perspective', there is identified a particular relationship with 'informal' control. The formal control of law is juxtaposed with informal social controls and the relationship is unequivocal: law varies inversely with other social controls (Black 1978, Hagan et al. 1979). The position advanced is that men are controlled by formal controls and women are controlled by informal controls (specifically the 'informal control process of childcare': Hagan et al. 1979: 27) -the model presents 'functional alternatives' and purports to explain the 
apparently differential sanctioning of conduct of men and women (see Barrett 1980: 236). And although the 'invisibility' of men and women in the private and public realms respectively is acknowledged (Hagan et al. 1979: 27), the ideological dimensions of this neat, static bifurcation of the world, and its coercive implications, are not interrogated.

This emphasis on formal and informal neither apprehends nor addresses the ideological character of the processes of the state and the law. It reproduces an image of society in which there is both a simple bifurcation between formal and informal and an implied continuum between the two (Hunt 1976, 1978): a reinforcement of the informal by the formal. To divide society unproblematically into two realms the formal and informal (or the public and the private) -is to neglect the ideological nature of these two 'discrete' realms and to ignore the nature of the relationship between the two. Indeed, insofar as it contributes to the notion that the 'formal' law either does not or ought not intrude into the ordinary and everyday workings of a smoothly running informal sphere, it distorts (and directs attention away from) the nature of the law's contribution to the construction of the 'public' and 'private' spheres. To put it at its simplest, one cannot opt out of the law and seek refuge in the invisibility and sanctuary of the 'informal' realm: as Julia Brophy and Carol Smart have argued, 'the law still has something [indeed much] to say about our domestic lives and intimate relations and we cannot assert its irrelevance by ignoring it' (1985: 1). The nature and social significance of 'informal' relationships may change; indeed, legislative initiatives of the 1970s in Canadian family law and the amended, expanded definitions of 'spouse' for the purpose of maintenance and child support, but significantly not property, bestowed a legal status upon previously 'subterranean' relationships. ${ }^{4}$ The 'family' is still defined by law, and notwithstanding gender neutral references to 'spouses' and 
'parent', it is still taken to mean male adult, female adult, and their biological or adopted children.

Feminists have identified the importance of the 'private sphere' and, at the same time, the essentially ideological nature of a reified split between the public and the private. For instance, while Tove Stang Dahl and Annika Snare (1978) identify the importance of the 'informal' control of women, in particular the male-dominated family household, their analysis expressly addresses the coercive nature of the 'informal' or 'private' sphere, with conflicting interests between wife and husband, and the 'status quo' effect of its invisibility (1978: 22). Further, they explicitly identify the role of the state in constructing and supporting the home as a private prison for women. As Michele Barrett has observed, 'This argument relies on a recognition of the role of the state in maintaining the myth of a separation of the public from the private sphere, according to which women are held to occupy a privileged (albeit at the same time restricted) place in the private arena' (1980: 23940). Gender becomes not simply a variable in 'sexual stratification': gender relations are social relations that are socially constructed, the subject and site of struggle, and in most social contexts the locus of the oppression of women.

\section{Law and the social control of women}

Renee Kasinsky's (1978) analysis of rape and the social control of women is illustrative of the instrumental and coercive emphasis of the critical social control perspective, as applied to women:

In addition to controlling and psychologically assaulting the rape victim, the law 
and legal practices also exert social control over the entire female population through the wide fear of rape. The law and court processes help legitimize the assailants' actions through the lack of prosecution. Women soon learn that they cannot rely upon the authority of the State, controlled by male interests, to protect themselves from rape (1978: 63).

In feminist accounts of social control, the 'social' is really 'male' and the 'control' emanates from the law, legal practices, the state all controlled by 'male interests' (see also Hanmer 1981). The 'social control' of women is thus achieved by the direct and instrumental manipulation of the law and the state by male interests (see also MacKinnon 1983).

As others have argued (see e.g. Petchesky 1984, Brophy and Smart 1985) there are both theoretical and practical limitations to this approach to law. In arguing that the law and the state represent the interests of men as a group, one is hard-pressed to offer a coherent explanation for changes in the law which have not resulted from 'male' pressure nor witnessed benefits for 'men' as a whole (for example, the repeal of spousal immunity in sexual assault legislation in Canada). Implicit as well in this position is the notion that 'male interests' may be understood to be unproblematically monolithic (Smart 1984) a position which is rich in polemics but will not withstand serious scrutiny, particularly if class, race and ethnicity are considered.

An insistence on both historical specificity and the importance of the role of law in 'organizing' consent is a recent theme in socio-legal research (see, e.g. , Hay 1975, Thompson 1975, Hall et al. 1978, Hall 1980). These issues are no less important for an understanding of the nature of the law's contribution to the oppression of women. And while the gaze must be broad, the focus must be precise. For instance, the 
reformist legislation of two periods of the post-war British state in the area of morality has been carefully analyzed. These legislative initiatives, which crossed the civil/criminal boundaries of legal classification, dealt, inter alia, with prostitution, suicide, obscenity in the first period (1950s)and with abortion, contraception, homosexuality and divorce in the later period (1960s) (Hall 1980). The thrust of the legislative reforms has often been characterized as one of liberalization and permissiveness (cf. Greenwood and Young 1980), although as Hall illustrates, the core of the tendency of the legislation was increased state regulation coupled with selective privatization (1980: 18). Although he examines the limited nature of some of the reforms, he cautions against posing the issue in 'too simple and binary a form' that is, viewing them as a tightening of control under the veneer of reform (1980: 18). The message of the legislation was directed toward the regulation of morality: 'that is, inevitably it was about sexual practice' (1980: 20). The target of the 'message' was not simply the 'problem' population directly affected by the legislation (for example, homosexual men, consumers of sexual services, obscene literature and so on); rather, Hall argues, the principal object/subject of the legislation was the position of women -a reshaping of the field of female sexual conduct (see also Smart 1981). Rather than identifying simply the limits of reform, Hall insists that the issue must be approached with a more theoretically informed perspective:

This attempt to reshape the field of female sexual conduct must be set in the context of other practices and discourses concerning women in the period, and against the material conditions affecting their position (1980: 21). 
The two periods witnessed somewhat different thrusts, the legislation of the $1950 \mathrm{~s}$ being involved in the more general ideological campaign -characterized by the 'reconstruction of femininity' (1980:21) -to return women to the home, marriage and family. The economic policy and planning of the British state promoted, and was thought to depend upon, consumption within the 'private and familial sphere' and 'women had to be located at the heart and centre of the principal unit of consumption, the family' (1980: 23). In the 1960s, the combined effect of the growing women's movement and wider access to abortion and contraception facilitated the 'partial break' with the domestic ideal of the 1950s.

If one is committed to developing a coherent explanation of the impact and significance of this constellation of legislation which attempted to reconstruct sexual practices, it is clear that the 'law as social control' couplet is too blunt and imprecise an analytical instrument to detail the full social significance thereof. It can be argued, for instance, that the 'named' targets of individual pieces of legislation were not necessarily those most affected; nor is it tenable to argue that the net effect of the 'restructuring' of the field of female sexual practice was simply the widening of the net of control over women's sexuality (although a strong argument can be made with respect to the punitive control of prostitutes see Smart 1981), because some of the legislation gave women some room to manoeuvre, either directly as in abortion law reform (cf. Mackinnon 1983) or indirectly as in the case of divorce law reform. The sustained support of the British state in the post-war period for a particular model of family household and familial ideology (through social policy and legislative initiatives) was far more problematic for women (see Mcintosh 1978, Barrett 1980, Taylor 1981).

When applied to women then, the 'law as social control' perspective neglects this important insight that the position and importance of law shifts in different historical 
contexts (Hall 1980). These shifts are neither simply nor easily imposed from 'above' but may be forced from 'below' through resistance, opposition and struggle (see, for example, Linebaugh 1975). This is as true of women's struggles and resistance as it is for other social groups. To understand the significance of different forms of struggle one requires, as Stuart Hall and his colleagues have argued, a 'more differentiated historically located analysis':

In such a perspective, it is precisely the whole repertoire of struggle strategies, positions, solutions which must inform the analysis, and which throws a revealing light back onto those sections of the [working] class taking or driven along the specific path of 'criminalisation' (1978: 188).

Changes in legal definitions and categories of crime, or indeed in legal reforms generally, must be understood within the context of struggle not simply as concessions granted voluntarily, benevolently or with 'manipulation aforethought'. This is as important for an understanding of the nature of and significance of class struggle historically as it is for an understanding of the historical contexts of women's struggles for equality at law.

In nineteenth and early twentieth-century England, the development of the notion of the importance of mothers to young children, and indeed the ideology of motherhood (see Davin 1978) was inextricably bound up with a long struggle by women to challenge the bald patriarchal principles of the English law of husband and wife (see Brophy and Smart 1981), which had long held that the children of a marriage were the children of the father. In this century, the ideology of 'motherhood' has reinforced the notion that woman's proper place is in the home and that her secondary position is in the work force. Still, some ground in real 
terms was gained by women within the family by virtue of the 'privileging' of women's/mothers' importance to children (in the best interests of the children). Similarly, Smart's (1984) analysis illuminates the shifting terrain of law, and shows that in different social contexts, the meaning and impact of the same piece of legislation may be profoundly contradictory as in the case of matrimonial property law in the late nineteenth century, when legislation for the first time provided for the ownership of separate property by married women, to the 1950s, when courts interpreted the right to own separate property to mean an ability to make equal contributions to acquisition of property. Thus the principle of formal equality enshrined in the nineteenth-century legislation was used by twentieth-century courts against married women unable to demonstrate any real (financial) contribution to the family home.

Clearly, the social position of women is intimately connected with regulation by the state: even pregnancy and childbirth are closely regulated as demonstrated by the struggle around midwifery and homebirths. To ignore the 'formal' or to too narrowly define it is to miss completely the myriad complex and contradictory ways in which the state ensures and reproduces women's subordination. However, as Mary Mcintosh (1981) reminds us, in the current context neither socialists nor feminists can afford 'the luxury of a purely critical stance' vis-a-vis the state. This is particularly appropriate in the context of conservative governments' targeting such parts of the 'control apparatus' as welfare, education and health care all of which have been key arenas for women's employment since the second world war (see Armstrong 1984). Women have much to lose when the 'control apparatus' is attacked. Indeed, as Rosalind Petchesky has argued, 'the "gatekeepers" to reproductive services are more often women, who as counselors, nurses, physicians, and agency 
bureaucrats mediate state reproductive policies sometimes progressively' (emphasis in original (1984: 67). Clearly the locus-if one can be identified -of the 'control' of women is neither primarily 'informal' nor totally determined by a monolithic (male or capitalist) state.

\section{Conclusion}

In this paper we have undertaken what we regard as a preliminary critique of the concept of 'social control' and its utility for a critical criminology in Canada. In tracing its emergence and historical development as a key concept in American sociology, we have illustrated that its ascendancy represented a victory for liberal sociology. The recent attempts by critical criminologists and sociologists to rehabilitate the concept of 'social control' by insisting upon the essentially coercive nature of control have not resulted in an advance over traditional theorizing.

By examining the 'women, law and social control' literature, in particular the use of the 'formal/informal' dichotomy, we have attempted to illustrate the limited utility of the concept for developing an historically and theoretically informed understanding of the complex and contradictory relationship of women to the state and law. The concept of 'social control' is ahistorical: when coupled with law, moreover, it lends itself to instrumentalism. It is our view that the concept of 'social control' ought to be abandoned by critical scholars in favour of one attentive to the dynamic complexity of history, struggle and change.

\section{Acknowledgement}

We wish to thank Judy Deverell for her assistance in the preparation of this paper, and Stan Cohen and Ian Taylor for their valuable comments. 


\section{Notes}

1. See, for example, how the concept of social control is employed in: Greenaway and Brickey (1978), Hanmer (1981), Cohen and Scull (1983), Anderson and Davis (1983), Schur (1984), Boyd (1986), Menzies, Lowman and Palys (1987).

2. The concept of 'social control' is, of course, inextricably bound up with the equally problematic concept of 'deviance' (Sumner 1983).

3. Although we are concerned with sociological conceptions of 'social control', it should be noted that nonsociological formulations have also been extremely influential, both in the past and at the present point in time (Zimring and Hawkins1973).

4. The Family Relations Act, R.S.B.C. 1979, c. 121, s. 1, defines spouse as a wife or a husband and includes

(c) except under Part 3, a man or woman not married to each other, who lived as husband and wife for a period of not Jess than 2 years, where an application under this Act is made by one of them against the other not more than one year after the date they ceased living together as husband and wife.

This expanded definition of spouse is excepted under the important Part 3 of the legislation which pertains to family property and assets; for the purpose of property ownership, the spouse must be a 'legal' spouse.

The Ontario legislation is similar; however, 'spouse' is more narrowly defined in the defini- tion section to mean either of a man and woman who 'are married to each other' or 'who have entered into a marriage that is voidable or void in good faith on the part of the person asserting a right under this Act'. (Family Law Act, S.O., 1986, c. 4, as amended by 1986, c. 5, s. 1(1)). The expanded definition of 'spouse' is contained only in the part of the Act which relates specifically to support obligations; s. 29 defines a spouse as follows:

29. In this Part,

'spouse' means a spouse as defined in subsection 1(1), and in addition includes either of a man and woman not being married to each other and have cohabited,

(a) continuously for a period of not Jess than three years, or

(b) in a relationship of some permanence if they are the natural or adoptive parents of a child.

\section{References}

Adlam, D. and Rose, N. (1981). 'The Politics of Psychiatry', Politics and Power 4: 165-202.

Anderson, B. and Davis, N.J. (1983). Social Control. New York: Irvington Publishers. Armstrong, P. (1985). Labour Pains. Toronto: Women's Press.

Barrett, M. (1980). Women's Oppression Today: Problems in Marxist Feminist Analysis. London: Verso. Barrett, M. and Mcintosh, M. (1982). The Anti-Social Family. London: Verso. Black, D.J.

(1976). The Behavior of Law. New York: Academic Press.

Black, D.J. (1978). 'The Boundaries of Legal Sociology', in: Reasons, C.E. and Rich, R.M. (eds),

The Sociologyof Law,pp. 97-113. Toronto: Butterworths.

Boyd, N. (ed.) (1986). The Social Dimensions of Law. Scarborough: Prentice-Hall.

Brophy, J. and Smart, C. (1981). 'From Disregard to Disrepute: The Position of Women in Family Law', FeministRev.9: 3-16.

Brophy,J.andSmart,C.(eds)(1985).Women inLaw:ExplorationsinLaw,Familyand Sexuality. London: Routledge and K. Paul.

Brown, J. (1978). 'Social Control and the Modernization of Social Policy, 1890-1929', in: Thane,

P. (ed.), The Origins of British Social Policy, pp. 126--146. London: Croom Helm. Cain, M.

(1985). 'Beyond Informal Justice', Contemporary Crises 9: 335-373.

Chambliss, W.J. and Mankoff, M. (eds) (1976). Whose Law? What Order? New York: Wiley. Clark,

A.L.and Gibbs, J.P.(1965).'Social Control:A Reformulation',SocialProblems12: 398-415.

Cohen, S. (1979). 'The Punitive City: Notes on the Dispersal of Social Control', Contemporary Crises 3(4): 339-363.

Cohen, S. (1983). 'Social Control Talk: Telling Stories About Correctional Change', in: Garland,

D. and Young, P. (eds), The Power to Punish, pp. 101-129. London: Heinemann. Cohen, S.

(1985). Visions of Social Control. Cambridge: Polity Press. 
Cohen, S. and Scull, A. (1983). 'Introduction: Social Control in History and Sociology', in: Cohen, S. and Scull, A. (eds), Social Control and the State, pp. 1-14. Oxford: Martin Robert- son.

Cooley, C.H. (1966). Social Process. Carbondale: Southern Illinois Univ. Press.

Corrigan, P. and Sayer, D. (1980). 'How the Law Rules: Variations on Some Themes in Karl Marx', in: Fryer, B. et al. (eds), Law, State and Society, pp. 21-53. London: Croom Helm.

Coward, R. (1982). 'Sexual Violence and Sexuality'. Feminist Rev. 11: 9-22.

Davin, A. (1978). 'Imperialism and Motherhood'. Hist. Workshop (5, Spring): 9-65.

Davis, N.J. (1980). Sociological Constructions of Deviance. Dubuque, Iowa: Wm. C. Brown. Downes,

D. and Rock, P. (1982). Understanding Deviance. Oxford: Clarendon Press.

Garland, D. (1981). 'The Birth of the Welfare Sanction', British J. of Law and Society 8: 29-45.

Garland, D. (1983). 'Durkheim's Theory of Punishment: A Critique', in: Garland, D. and Young,

P. (eds), The Power to Punish, pp. 37-61. London: Heinemann. Garland, D.

(1985). Punishment and Welfare. Brookfield, Vt.: Gower.

Garland, D. and Young, P. (1983). 'Toward a Social Analysis of Penality', in: Garland, D. and Young,

P. (eds), The Power to Punish, pp. 1-36. London: Heinemann.

Garland, D. and Young, P. (eds) (1983). The Power to Punish. London: Heinemann.

Geis, G. (1964).'Sociologyand Sociological Jurisprudence:Admixture of Lore and Law',

Kentucky Law J. 52: 267-293.

Gibbons, D.C. (1979). The Criminological Enterprise. Englewood Cliffs, N.J.: Prentice-Hall. Gibbs, J.P.

(1977). 'Social Control, Deterrence and Perspectives in Social Order', Social Forces

56(2): 408-423.

Gibbs, J.P. (1982) 'Law as a Means of Social Control', in: Gibbs, J.P. (ed.), Social Control: Views fromthe Social Sciences, pp. 83-113. Beverly Hills, CA: Sage.

Gouldner, A.W. (1970). The Coming Crisis of Western Sociology. London: Heinemann. Greenaway,W.and Brickey,S.(1978).LawandSocialControl in Canada.Scarborough:

Prentice-Hall.

Hagan, J., Simpson, J.H. and Gillis, A.R. (1979). 'The Sexual Stratification of Social Control: A Gender-

Based Perspective on Crime and Delinquency', British J. of Sociology 30(1): 25-38.

Hall, S. (1980). 'Reformism and the Legislation of Consent', in: National Deviancy Conference (ed.),

Permissiveness and Control: The Fate of the Sixties Legislation, pp. 1-43. London: MacMillan.

Hall, S. (1984). 'The Rise of the Representative Interventionist State 1880s-1920s', in: McLennan,

G. et al. (eds), State and Society in Contemporary Britain, pp. 7-49. Cambridge: Polity Press. Hall, S. et al. (1978). Policing the Crisis. London. Macmillan.

Hanmer, J. (1981). 'Male Violence and the Social Control of Women', in: Feminist Anthology Collective (ed.), No Turning Back, pp. 190--195. London: Women's Press.

Hay, D. (1975). 'Property, Authority and the Criminal Law', in: Hay, D. et al., Albion's Fatal Tree: Crime and Society in EighteenthCentury England, pp, 17-63. New York: Pantheon.

Hay, J. (1978). 'Employers' Attitudes to Social Policy and the Concept of "Social Control", 1900-1920', in: Thane, P. (ed.), The Origins of British Social Policy, pp. 107-125. London: Croom Helm. Hirschi, T. (1969). Causes of Delinquency. Los Angeles: Univ. of California Press.

Hunt, A. (1976). 'Perspectives in the Sociology of Law', in: Carlen, P. (ed.), The Sociology of Law, pp. 22-44. Keele: Univ. of Keele (Sociological Monograph \#23).

Hunt, A. (1978). The Sociological Movement in Law. Philadelphia: Temple Univ. Press.

Hunt, A. (1981a). 'Marxism and the Analysis of Law', in: Podg6recki, A. and Whelan, C.J. (eds),

Sociological Approachesto Law, pp. 91-110. London: Croom Helm. Hunt, A.

(1981b). 'The Politics of Justice', Politics and Power 4: 3-26.

Hunt, A. (1982). 'Dichotomy and Contradiction in the Sociology of Law', in: Beirne, P. and Quinney, R. (eds), Marxism and Law, pp. 74-97. New York: John Wiley \& Sons.

Janowitz, M. (1975). 'Sociological Theory and Social Control', American J. of Sociology 81(1): 82-108.

Janowitz, M. (1976). Social Control of the Welfare State. New York: Elsevier.

Janowitz, M. (1978). The Last Half Century. Chicago: Univ. of Chicago Press.

Kasinsky, R. (1978). 'Rape: The Social Control of Women', in: Greenaway, W.K. and Brickey,

S.L. (eds), Law and Social Control in Canada, pp. 59-69. Scarborough: Prentice-Hall.

Kingdom, E. (1985). 'Legal Recognition of a Woman's Right to Choose', in: Brophy, J. and Smart, C. (eds), Women in Law: Explorations in Law, Family and Sociology, pp. 143--161. London: Routledge and K. Paul. 
Lemert, E.M. (1951). Social Pathology. New York: McGraw-Hill.

Lemert, E.M. (1967). Human Deviance, Social Problems and Social Control. Englewood Cliffs, N.J.: Prentice-Hall.

Linebaugh, P. (1975). 'The Tyburn Riot Against the Surgeons', in: Hay, D. et al., Albion's Fatal Tree, pp. 65-117. New York: Pantheon.

MacKinnon, C.A. (1983). 'Feminism, Marxism, Method and the State: Toward a Feminist Jurisprudence', Signs 8(4): 635-658.

Mcintosh, M. (1978). 'The State and the Oppression of Women', in: Kuhn, A. and Wolpe, A.M. (eds), Feminism and Materialism, pp. 254-289. London: Routledge and K. Paul.

Mcintosh, M. (1981). 'Feminism and Social Policy', Critical Social Policy 1(1): 32-42. Matza, D.

(1969). Becoming Deviant. Englewood Cliffs, N.J.: Prentice-Hall.

Mayer, J.A. (1983). 'Notes Toward a Working Definition of Social Control in Historical Analy- sis', in: Cohen, S. and Scull, A. (eds), Social Control and the State, pp. 17-38. Oxford: Martin Robertson.

Melossi, D. (1985). 'Overcoming the Crisis in Critical Criminology: Toward a Grounded Labeling Theory',Criminology 23(2): 193-208.

Menzies, R.J. (1983). 'A Farewell to Norms: Black's Theory of Law Revisited', in: Fleming, T. and Visano, L. (eds), Deviant Designations: Crime, Law and Deviance in Canada, pp. 433-449. Toronto:Butterworths.

Menzies, R.J., Lowman, J. and Palys, T. (eds) (1987). Transcarceration: Essays in the Sociology of Social Control. Aldershot: Gower.

Muraskin, W.A. (1976). 'The Social-Control Theory in AmericanHistory: A Critique', J. of Social History10: 559-569.

Park, R.E. and Burgess, E.W. (1969). Introduction to the Science of Sociology. 3rd ed. Chicago: Univ. of Chicago Press.

Parsons, T. (1951). The Social System. Glencoe, Ill.: The Free Press.

Pashukanis, E.B. (1978). Law and Marxism. Introduction by C. Arthur. London: Ink Links. Petchesky,

R. (1984). 'Abortion as "Violence Against Women": A Feminist Critique', Radical America18: 64-68.

Pisciotta, A. (1981). 'Corrections, Society and Social Control in America: A Metahistorical Review of the Literature', Criminal Justice Review 2: 109-130.

; Platt, A. (1977). The Child-Savers. Rev. ed. Chicago: Univ. of Chicago Press.

Pound, R. (1930). Criminal Justice in America. Reprint. New York: DaCapo Press, 1972.

Pound, R. (1942). Social Control Through Law. New Haven: Yale Univ. Press.

Pound, R. (1943). 'Sociology of Law and Sociological Jurisprudence', Univ. of Toronto Law J. 5(1): $1-20$.

Quinney, R. (1974). Critique of Legal Order. Boston: Little, Brown.

Ratner, R.S. and McMullen, J .L. (1985). 'Social Control and the Rise of the "Exceptional State" in Britain, the United States, and Canada', in: Fleming, T. (ed.), The New Criminologies in Canada: State, Crime and Control, pp. 185-205. Toronto: Oxford Univ. Press.

Reckless, W. (1961). 'A New Theory of Delinquency and Crime', Federal Probation 25 (Dec.): 42-46.

Ross, E.A. (1969). Social Control. Cleveland: Case Western Reserve Univ. Press.

Rothman, D.J. (1980). Conscience and Convenience. Boston: Little, Brown.

Rothman, D.J. (1981). 'Social Control: The Uses and Abuses of the Concept in the History of Incarceration', RiceUniv. Studies 67(1): 9-20.

Rowbotham, S. (1981). 'The Trouble with "Patriarchy", in: Samuel, R. (ed.), People's History and Socialist Theory, pp. 364-369. London: Routledge and K. Paul.

Schwendinger, H. and Schwendinger, J. (1974). The Sociologists of the Chair. New York: Basic Books.

Schur, E.J. (1984). Labelling Women Deviant: Gender, Stigma and Social Control. New York: Random House.

Scull, A. (1977). Decarceration. Englewood Cliffs, N.J.: Prentice-Hall.

Scull, A. (1981). 'Progressive Dreams, Progressive Nightmares: Social Control in 20th Century America', Stanford Law Rev. 33: 575-590.

Scull, A. (1983). 'Community Corrections: Panacea, Progress or Pretence?', in: Garland, D. and Young, P. (eds), The Power to Punish, pp. 146-165. London: Heinemann.

Scull, A. and Cohen, S. (eds). (1983). Social Control and the State: Historical and Comparative Essays. Oxford: Martin Robertson.

Smart, C. (1981). 'Law and the Control of Women's Sexuality-The Case of the 1950s', in: Hutter, B. and 
Williams, G. (eds), Controlling Women: The Normal and the Deviant, pp. 40-60. London: Croom Helm.

Smart, C. (1984). The Ties That Bind: Law, Marriage and the Reproduction of Patriarchal Relations. London: Routledge and K. Paul.

Smart, C. (1985). 'Legal Subjects and Sexual Objects: Ideology, Law and Female Sexuality', in: Brophy, J. and Smart, C. (eds), Women in Law, pp. 50-70. London: Routledge and K. Paul.

Spitzer, S. (1975). Toward a Marxian Theory of Deviance. Social Problems 22(5): 638--651. Stang Dahl, T. and Snare, A. (1978). 'The Coercion of Privacy: A Feminist Perspective', in:

Smart, C. and Smart, B. (eds), Women, Sexualityand Social Control, pp. 8-26. London: Routledge and K. Paul.

Stedman Jones, G. (1977). 'Class Expression versus Social Control? A Critique of Recent Trends in the Social History of "Leisure"', History Workshop (4, Autumn): 162-170.

Sugarman, D. (1983). 'Law, Economy and the State in England, 1750-1914: Some Major Issues', in: Sugarman, D. (ed.), Legality, Ideology and the State, pp. 213-266. London: Academic Press. Sumner, C. (1983). 'Rethinking Deviance: Toward a Sociology of Censures', Research in Law,

Deviance and Social Control 5: 187-204.

Tannenbaum, F. (1938). Crime and the Community. New York: Columbia Univ. Press. Thompson, E.P. (1975). Whigs and Hunters. Middlesex: Penguin.

Taylor, I. (1981). Law and Order: Arguments for Socialism. London: Macmillan.

Taylor, I. (1983). Crime, Capitalism and Community: Three Essays in Socialist Criminology.

Toronto: Butterworths.

Unger, R. (1976). Law in Modern Society. New York: Free Press.

Yago, S. (1981). Law and Society. Englewood Cliffs, N.J.: Prentice-Hall.

Young, J. (1979). 'Left Idealism, Reformism and Beyond: From New Criminology to Marxism', in: Fine, B. et al. (eds), Capitalism and the Rule of Law, pp. 11-28. London: Hutchinson.

Zimring, F.E. and Hawkins,G.J. (1973). Deterrence:The LegalThreat in Crime Control.

Chicago: Univ. of Chicago Press. 